\title{
Intake of Spineless Cladodes of Opuntia ficus-indica During Late Pregnancy Improves Progeny Performance in Underfed Sheep
}

\author{
Venancio Cuevas Reyes ${ }^{1}$, Francisco Santiago Hernandez ${ }^{2}$, Manuel de Jesus Flores Najera ${ }^{3}$, \\ Juan Manuel Vazquez Garcia ${ }^{4}$, Jorge Urrutia Morales ${ }^{2}$, Morteza Hosseini-Ghaffari ${ }^{5}$, \\ Alfonso Chay-Canul ${ }^{6}\left(\mathbb{D}\right.$, César A. Meza-Herrera ${ }^{7}(\mathbb{D})$, Antonio Gonzalez-Bulnes ${ }^{8}{ }^{(D)}$, \\ Graeme B. Martin ${ }^{9}$ and Cesar A. Rosales Nieto ${ }^{3, *(D)}$ \\ 1 Instituto Nacional de Investigaciones Forestales, Agrícolas y Pecuarias, \\ Campo Experimental Valle de México, Texcoco 56250, Ciudad de México, Mexico; \\ cuevas.venancio@inifap.gob.mx \\ 2 Instituto Nacional de Investigaciones Forestales, Agrícolas y Pecuarias, Campo Experimental San Luis, \\ San Luis Potosí 78431, Mexico; santiago.francisco@inifap.gob.mx (F.S.H.); \\ urrutia.jorge@inifap.gob.mx (J.U.M.) \\ 3 Instituto Nacional de Investigaciones Forestales, Agrícolas y Pecuarias, Campo Experimental La Laguna, \\ Matamoros 27440, Coahuila, Mexico; flores.manuel@inifap.gob.mx \\ 4 Facultad de Agronomía y Veterinaria, Universidad Autónoma San Luis Potosí, San Luis Potosí 78321, \\ Mexico; manuelvazquez87@yahoo.com.mx \\ 5 Institute of Animal Science, Physiology \& Hygiene Unit, University of Bonn, 53115 Bonn, Germany; \\ morteza1@uni-bonn.de \\ 6 División Académica de Ciencias Agropecuarias, Universidad Juárez Autónoma de Tabasco, \\ Carr. Villahermosa-Teapa, km 25, Villahermosa 86280, Tabasco, Mexico; aljuch@hotmail.com \\ 7 Unidad Regional Universitaria de Zonas Áridas, Universidad Autónoma Chapingo, Ciudad Juárez 35230, \\ Bermejillo, Mexico; cmeza2020@hotmail.com \\ 8 Departamento de Reproducción Animal, INIA, 28040 Madrid, Spain; bulnes@inia.es \\ 9 UWA Institute of Agriculture, University of Western Australia, Crawley, WA 6009, Australia; \\ graeme.martin@uwa.edu.au \\ * Correspondence: nieto_cesar@hotmail.com; Tel.: +52-4448261314
}

Received: 18 April 2020; Accepted: 3 June 2020; Published: 7 June 2020

Simple Summary: Plants in the Opuntia genus are abundant and can be used as a feed supplement because they are highly digestible and can provide water and energy.We fed sheep during late gestation with alfalfa (Control), Opuntia (Opuntia) or protein-enriched Opuntia (E-Opuntia) and measured milk yield and postnatal growth in the progeny. Birth weight did not differ among treatments $(p>0.05)$ but progeny from E-Opuntia grew faster $(p<0.01)$ and were heavier at weaning $(p<0.05)$, despite the fact that Control ewes produced more milk $(p<0.05)$. Feeding ewes with Opuntia (protein enriched or not) during the last third of gestation is an option for reducing production costs in underfed females managed under extensive conditions in arid and semiarid regions.

Abstract: The present study tested whether feeding ewes during the last third of pregnancy with cladodes of Opuntia (untreated or protein-enriched), as an alternative to alfalfa hay, would improve milk yield as well as the pre- and post-natal growth of their lambs. Sixty mature Rambouillet ewes and their progeny were randomly allocated among three nutritional treatments: (i) Control, fed alfalfa; (ii) Opuntia, fed untreated cladodes; (iii) E-Opuntia, fed protein-enriched cladodes (pre-treated with urea and ammonium sulphate). Birth weight did not differ among treatments $(p>0.05)$ but Control ewes produced more milk than both groups of Opuntia-fed ewes $(p<0.05)$. However, milk yield was not related to the growth of the progeny $(p>0.05)$ because lambs from E-Opuntia-fed ewes grew faster $(p<0.01)$ and were heavier at weaning $(p<0.05)$ than lambs from the other two groups. We conclude 
that Opuntia (with or without protein enrichment) can be used as an alternative to alfalfa hay for feeding ewes during the last third of pregnancy and therefore reduce production costs under extensive conditions in arid and semiarid regions. Moreover, protein-enriched Opuntia appears to improve postnatal lamb growth.

Keywords: birth weight; cactus; Opuntia spp.; postnatal performance; sheep

\section{Introduction}

The breeding of small ruminants is often the principal economic output in the arid and semiarid regions of the world. Animals raised under these conditions depend solely on the forage resources from these usually degraded rangelands, and generally do not receive any nutritional supplementation $[1,2]$ because high-quality pastures and concentrates are not readily available and usually too expensive [3].

A possible low-cost alternative is to make use of autochthonous plants, such as cacti (Opuntia spp.) and ball moss (Tillandsia recurvata) [4-6]. Opuntia spp. offer a high water content, high digestibility and significant amounts of energy [7,8]. In cladodes of the spineless cactus, Opuntia ficus-indica, the protein content ranges from $2.8-8 \%$ [7-10], the fat content ranges from 3.9-4.7 g/100 g DM [9] and the content of metabolisable energy ranges from 11.1-11.4 mj/kg DM [10], with some variation according to age and genotype. Opuntia adapts easily to poor-quality soils, withstands water shortages and high temperatures [11,12], and is widely distributed across Latin America, South Africa and the Mediterranean region $[10,13]$.

Previous studies have shown that feeding female sheep and goats with Opuntia cladodes can improve reproductive performance and the growth of their offspring post-weaning, suggesting that Opuntia is a viable alternative for nutritional management of small ruminants in arid and semiarid conditions [14-17]. Particularly important is the period that includes late gestation and early lactation because the female must transition from a non-lactating lipogenic status into one of high demand for energy to support the growth of fetuses and the newborn [18]. In contrast with its ability to supply energy, Opuntia cladodes contain low and variable amounts of protein $[7,8]$. This problem can be overcome to some extent by adding urea $(1 \%)$ or by fermentation with various additives [17,19-21]. These treatments enhance the dry matter intake and digestibility of Opuntia [22,23]. Enhancing the nutritive value of the maternal diet during the last trimester of gestation can improve colostrum quality [24], especially when the nutritive quality of the feedstuff is low. Previous work has shown that Opuntia cladodes can also fill this role in sheep, increasing the production, immunoglobulin G concentration and energy content of colostrum $[4,15]$. However, the effect on birth weight remains unknown. Thus, in the absence of sufficient information, we tested whether feeding Opuntia cladodes (untreated or protein enriched), as a substitute for alfalfa hay, during the last trimester of gestation would increase milk yield and birth weight, and accelerate lamb growth.

\section{Materials and Methods}

\subsection{Ethics Statement}

The study was conducted during the breeding period on a commercial farm in northern Mexico $\left(22^{\circ} 15^{\prime} \mathrm{N}, 100^{\circ} 52 \mathrm{~W}\right)$. All procedures in this study are consistent with International [25] and National [26] Research Council's Guide for the Care and Use of Laboratory Animals, with institutional approval reference number 10561934075.

\subsection{Animals and Experimental Procedure}

A total of 60 pregnant Rambouillet ewes were naturally mated and 43 of them, with the same days of pregnancy, and their progeny (33 females and 21 males) were used to investigate the effect of 
maternal diet during the last third of gestation (from Day $100 \pm 3$ of pregnancy to delivery) on birth weight and postnatal growth. Sheep were dewormed before mating with a commercially available product containing $1 \mathrm{~g}$ ivermectin (Baymec ${ }^{\circledR}$; Bayer, Mexico). Additionally, all ewes had received an intramuscular injection of commercially available products containing $0.005 \mathrm{~g}$ of vitamin $\mathrm{B} 12$ (Catosal ${ }^{\circledR}$; Bayer, Mexico), and 500,000 IU of vitamin A, 75,000 IU of vitamin D3 and $50 \mathrm{mg}$ of vitamin E (Vigantol ${ }^{\circledR}$; Bayer, Mexico). Sheep had free access to clean water and a block of mineral salts containing at least 17\% $\mathrm{P}, 3 \% \mathrm{Mg}, 5 \% \mathrm{Ca}$, and 75\% NaCL.

The experimental protocol is shown in Figure 1. Ewes were naturally mated with trained rams for 34 days (two full reproductive cycles, mostly during August). Pregnancy, number of fetuses and gestational age were assessed three times between 30 to 45 days after the start of mating, by transabdominal ultrasonography (Samsung-Medison SA-600 fitted to a $4 \mathrm{MHz}$ convex probe; Samsung Co. Seoul, South-Korea). Gestational age was estimated by assessing fetometric parameters: uterine depth (in early pregnancy), fetal crown-rump length, fetal biparietal diameter, and calcification of the fetal ribs and skull [27].

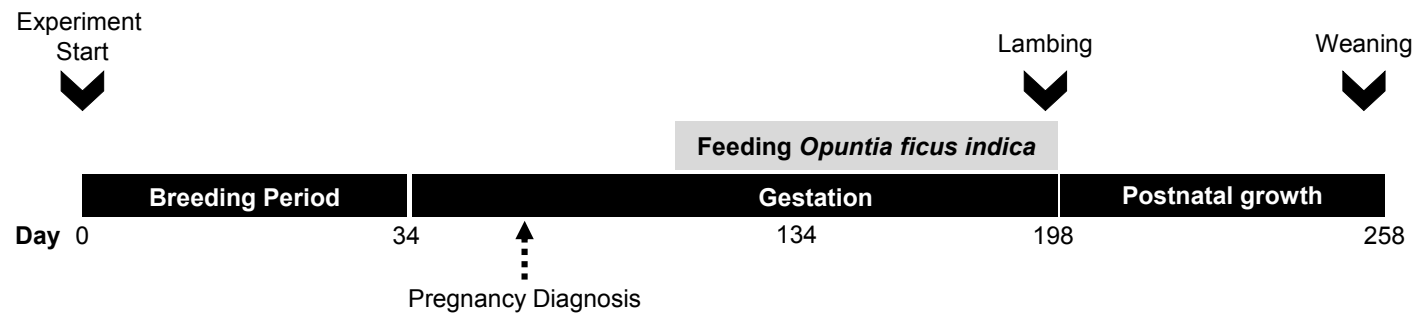

Figure 1. Schematic representation of the experimental design. Day 0 represents the day when the males were introduced and the breeding period started. Dietary treatments began around day 100 of gestation and continued until lambing.

On estimated gestational day $100 \pm 3$, the ewes were randomly allocated among three pens, one for each dietary treatment, ensuring the average body weights of the groups were similar. The treatments were alfalfa (Control; $n=11 ; 9$ singletons and 2 set of twins), untreated Opuntia (Opuntia; $n=14$; 9 singletons and 5 set of twins) and protein-enriched Opuntia (E-Opuntia; $n=18 ; 14$ singletons and 4 set of twins; see details below). Feed was provided in a fence-line feeder with sufficient space to minimize competition and allow every animal to consume its feed allocation.

\subsection{Experimental Diets}

Ewes were fed twice daily with dietary treatments from estimated gestational day $100 \pm 3$ up to lambing. The Control ewes were offered alfalfa hay ( $3 \%$ on the basis of their average body weight), whereas the ewes in the treatment groups were offered Opuntia or E-Opuntia diets. Opuntia cladodes were harvested daily and cut into small pieces to facilitate consumption. For the E-Opuntia treatment, cladodes were protein enriched by treating them with a solution containing $600 \mathrm{~g}$ urea and $80 \mathrm{~g}$ ammonium sulfate in $20 \mathrm{~L}$ of water. This solution was sprayed onto $100 \mathrm{~kg}$ of chopped cladodes and left for $24 \mathrm{~h}$. In both Opuntia treatments, each ewe was initially offered $500 \mathrm{~g}$ per day and the amount was gradually increased to $3 \mathrm{~kg}$ per day. Food refusals were quantified on a pen basis but, after the two first days of the adaptation period, all of the diet offered was consumed. Therefore, on average the dry matter intake for the control treatment was $1.3 \mathrm{~kg}$ per animal/day and $0.78 \mathrm{~kg}$ per animal/day for both Opuntia treatments. All ewes were fed to meet their nutritional requirements but, during the last third of gestation, the amount offered was below the nutritional requirements for a dry ewe with low physical activity [28]. For instance, the diet in the control treatment was $27 \%$ above the protein requirements, but 57\% below the metabolizable energy; while in the diet in the Opuntia treatment was $63 \%$ below the protein requirements and 35\% below the metabolizable energy; whereas in the diet in the E-Opuntia treatment was 33\% below the protein requirements and $37 \%$ below the metabolizable 
energy (Table 1). During early lactation, the diet was based on alfalfa, oats straw and silo to meet the nutritional requirements [28].

Table 1. Nutrient composition (DM basis) of the diets offered during the last third of gestation and nutrient requirement for a $50 \mathrm{~kg}$ ewe [28].

\begin{tabular}{lccccccc}
\hline \multicolumn{1}{c}{ Treatment } & DM (\%) & CP (\%) & EE (\%) & CARB (\%) & NDF (\%) & ADF (\%) & ME (Mcal/kg) \\
\hline E-Opuntia & 26.4 & 7.3 & 1.5 & 41.6 & 35.8 & 17.9 & 2.1 \\
Opuntia & 26.7 & 4.0 & 2.9 & 47.1 & 32.0 & 21.5 & 2.2 \\
Control (alfalfa) & 93.5 & 13.9 & 1.0 & 19.0 & 53.0 & 39.0 & 1.5 \\
NRC requirement & & 10.9 & & & & & 3.4 \\
\hline
\end{tabular}

DM: Dry matter; CP: Crude Protein; EE: Ether Extract; CARB: Carbohydrates; NDF: Neutral Detergent Fiber; ADF: Acid Detergent Fiber; ME: Metabolizable energy.

The nutritional composition of diets including dry matter, maintenance energy, and crude protein were assessed by AGROLAB México S.A. de C.V. (Table 1).

\subsection{Maternal Live Weight}

Ewes were weighed weekly throughout the experiment and the measurement were used to determine body weight changes.

\subsection{Milk Yield}

Before feeding, milk yield was assessed every two weeks (on the same day of the week), from one week after birth until weaning, using the oxytocin protocol to elicit milk let-down [29,30]. In brief, the ewes were separated from their lambs and then hand milked 5 min after an intramuscular injection of oxytocin (20 IU mg ${ }^{-1}$; PiSA Agropecuaria, Hidalgo, Mexico) according to manufacturer's guidelines. The time of the first milking was recorded and, $3 \mathrm{~h}$ later, the ewes were re-milked following the same oxytocin protocol. The weight of the milk collected at the second milking and the exact time between the two milkings were recorded to allow estimation of the rate of milk yield. After the second milking, the ewes and lambs were reunited in the pen.

\subsection{Newborn Outcomes and Offspring Growth}

On the day of lambing, the date, sex, and birth weight were recorded. To measure growth rates, lambs were weighed weekly from birth until weaning (60 days). One twin-born lamb from the E-Opuntia treatment died so its weight was used only for the analysis of birth weight.

\subsection{Statistical Analysis}

Data were analyzed using SAS version 9.3 [31]. Birth weight, body weight gain and weaning weight of the progeny were analyzed using linear mixed model procedures (PROC-MIXED). Fixed effects in the model were treatment, birth type and progeny sex. Birth weight, body weight gain and weaning data were included as covariates as appropriate. Maternal body weight change and lamb body weight gain were fitted in a linear regression model of weight on time for each individual and estimates of the regression coefficients were obtained as a measure of change by unit time. Milk yield data were analyzed using a mixed linear model (PROC MIXED of SAS) with treatment as the fixed effect. For progeny birth weight, liveweight gain, and weaning weight, sex and birth type were included as independent covariates where appropriate. Sampling date was included as a repeated measure and a random effect. All two-way interactions among the fixed effects and covariates were included in each model and non-significant $(p>0.05)$ interactions were removed from the model. Significant differences among means for treatments within variables were analyzed using LSD of PROC GLM [31]. 


\section{Results}

\subsection{Effects of Supplementation on Maternal Traits}

As shown in Figure 2, ewe body weight did not differ among treatments at the beginning of the experiment $(p>0.05)$ but, at the end of the experiment, the differences between all treatments were significant $(p<0.001)$. The changes in ewe body weight differed among treatments $(p<0.001)$ and were $-84 \mathrm{~g} \mathrm{day}^{-1}$ (Control), $22 \mathrm{~g} \mathrm{day}^{-1}$ (Opuntia) and $-121 \mathrm{~g} \mathrm{day}^{-1}$ (E-Opuntia).

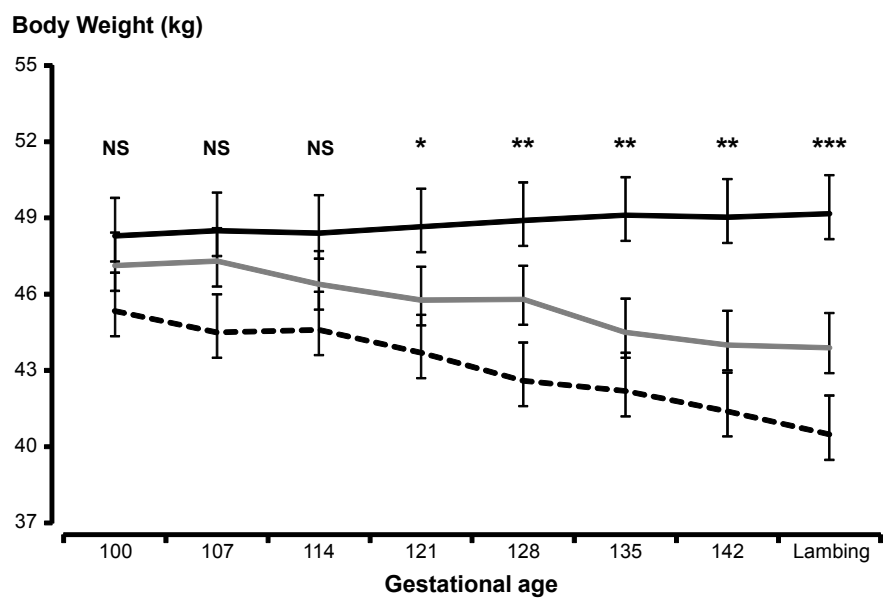

Figure 2. Body weight $( \pm \mathrm{SEM})$ of Rambouillet ewes that received alfalfa (Control; grey line), untreated Opuntia (black solid line), or protein-enriched Opuntia (black dotted line) during late gestation. NS: not significant; $*$ : $<0.05 ;{ }^{* *}: p<0.01 ;{ }^{* * *} p<0.001$.

Across the experiment, milk yield differed among treatments $(p<0.05)$, sampling dates $(p<0.001)$ and the interaction between these factors was significant $(p<0.05)$. During the first two samplings after lambing, milk yield was similar among treatments and did not change with time $(p>0.05$; Figure 3$)$. However, differences appeared at milk samplings $3(p<0.05)$ and $4(p<0.01)$, with Control ewes producing more milk than ewes in either of the Opuntia treatments (Figure 3). The interactions between treatment and birth type and between treatment and progeny sex were not significant $(p>0.05)$. After combining data across all treatment groups, milk yield tended to differ between birth types ( $p=0.07 ; 675 \mathrm{~mL}$ for singletons; $547 \mathrm{~mL}$ for twins) and with lamb sex ( $p=0.06 ; 540 \mathrm{~mL}$ for females; $670 \mathrm{~mL}$ for males). Neither daily bodyweight gain nor weaning weight were correlated with milk yield $(p>0.05)$.

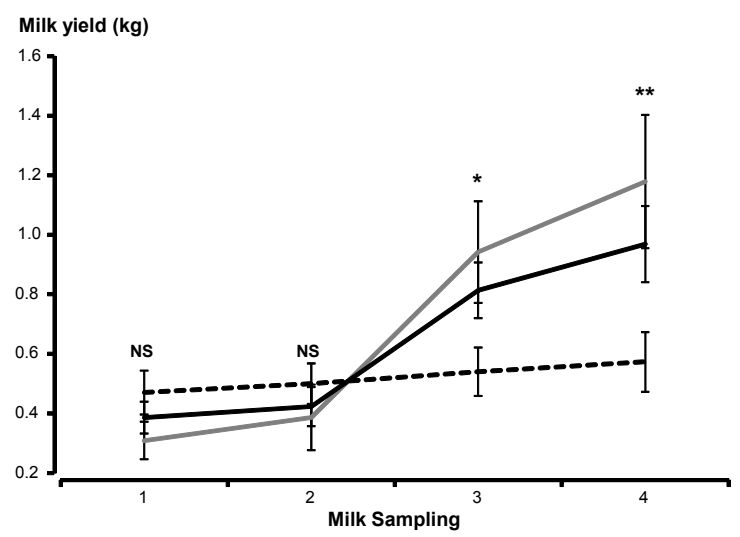

Figure 3. Milk yield ( \pm SEM) from week 1 up to weaning (60 days; sampling 4) in Rambouillet ewes that received alfalfa (Control; grey line), untreated Opuntia (black solid line), or protein-enriched Opuntia (E-Opuntia; black dotted line) during late gestation. NS: not significant; ${ }^{*} p<0.05 ;{ }^{* *} p<0.01$; *** $p<0.001$. 


\subsection{Progeny Birth Weight and Growth}

On average, the birth weight of the lambs from the CTL treatment was $3.7 \pm 0.1 \mathrm{~kg} ; 3.8 \pm 0.2$ for the lambs from the OP treatment and $3.7 \pm 0.1$ for the lambs from the ENR treatment. Birth weight did not differ among treatments ( $p>0.05$; Figure 4$)$. However, weight gain during the suckling period was significantly less in the Control group $\left(97 \pm 11 \mathrm{~g}\right.$ day $\left.^{-1}\right)$ and the Opuntia group $\left(97 \pm 9 \mathrm{~g} \mathrm{day}^{-1}\right)$ than in the E-Opuntia group $\left(128 \pm 19 \mathrm{~g} \mathrm{day}^{-1} ; p<0.01\right)$, leading to significantly greater weaning weight in the E-Opuntia group ( $p<0.05$; Figure 4 ). Maternal milk yield was not correlated with the weight gain or the weaning weight of the progeny $(p>0.05)$.

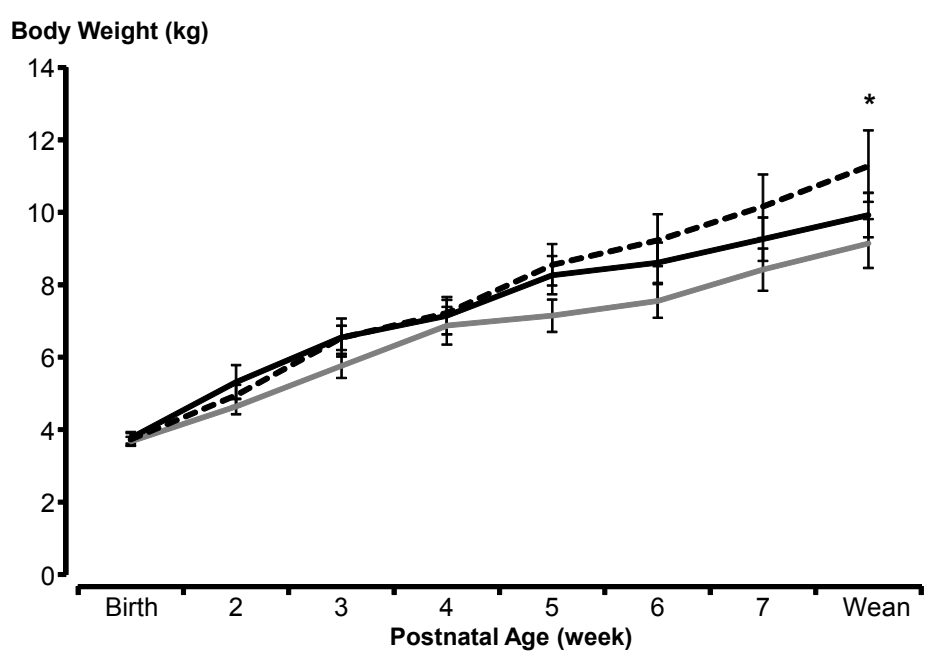

Figure 4. Body weight $( \pm$ SEM) from birth to weaning (Week 8) in the progeny of Rambouillet ewes that received alfalfa (Control; grey line), Opuntia (black solid line), or protein-enriched Opuntia (black dotted line) during late gestation. The data are combined for birth type (singleton and twins) and sexes.

Weaning weight differed among treatments $(p<0.05$; Figure 4). An orthogonal contrast revealed the difference between Control and E-Opuntia to be significant for body weight on weight sampling week 4 and onwards $(p<0.05)$.

In the Control treatment, singletons $(4.1 \pm 0.3 \mathrm{~kg})$ were heavier than twins at birth $(3.5 \pm 0.2 \mathrm{~kg}$; $p<0.05)$. However, the difference between male $(4.0 \pm 0.3 \mathrm{~kg})$ and female lambs from controls was not significant $(3.6 \pm 0.2 \mathrm{~kg} ; p>0.05)$. Daily live weight gain and weaning weights were similar between singletons and twins and between male and female lambs $(p>0.05)$.

Similarly, in the Opuntia treatment, singletons $(4.1 \pm 0.3 \mathrm{~kg})$ were heavier than twins at birth $(3.5 \pm 0.2 \mathrm{~kg} ; p<0.05)$, whereas no difference was observed between male $(4.0 \pm 0.3 \mathrm{~kg})$ and female lambs $(3.6 \pm 0.2 \mathrm{~kg} ; p>0.05)$. The daily live weight gain and weaning weights were similar between singletons and twins and between male and female lambs $(p>0.05)$.

In the E-Opuntia treatment, there were no differences in birth weight between sexes or between birth types $(p>0.05)$. However, in this group, male lambs grew faster $(200 \pm 44 \mathrm{~g} /$ day $)$ than female lambs $(97 \pm 14 \mathrm{~g} /$ day; $p<0.05)$ and therefore males were heavier at weaning $(15.0 \pm 2.3 \mathrm{~kg})$ than female lambs $(9.7 \pm 1.0 \mathrm{~kg} ; p<0.05)$. Daily live weight gain and weaning weight did not differ between singletons and twins $(p>0.05)$.

When all the lambs from all the treatments were combined for analysis (Table 2), the birth weights of male and females did not differ $(3.8 \pm 0.2$ vs. $3.7 \pm 0.1 ; p>0.05)$. From birth to weaning, however, males grew 35\% faster than females (130 \pm 16 vs. $\left.96 \pm 8 \mathrm{~g} \mathrm{day}^{-1} ; p<0.01\right)$ and were $21 \%$ heavier at weaning $(11.5 \pm 0.8$ vs. $9.5 \pm 0.5 ; p<0.05)$. In the combined groups, single-born lambs were heavier at birth than twin-born lambs $(3.9 \pm 0.1$ vs. $3.4 \pm 0.1 ; p<0.01)$ and grew $27 \%$ faster $\left(125 \pm 17\right.$ vs. $\left.98 \pm 8 \mathrm{~g} \mathrm{day}^{-1} ; p=0.09\right)$ so were $17 \%$ heavier at weaning $(11.2 \pm 0.9$ vs. $9.6 \pm 0.5$; $p<0.05)$. In the combined data for all lambs, the relationship between birth weight and body weight 
gain, and the relationship between birth weight and weaning weight, were not significant $(p>0.05)$. However, the weaning weight was positively related to weight gain $(p<0.001)$, with a $2.7-\mathrm{kg}$ increase in weaning weight for every $50 \mathrm{~g} \mathrm{day}^{-1}$ increase in weight gain.

Table 2. Combined data for all the lambs from all Rambouillet ewes in all treatment groups (Control, Opuntia and E-Opuntia) showing the effects of sex and birth type on birth weight, daily live weight gain, and weaning weight.

\begin{tabular}{ccccc}
\hline Variable/Sex type & Female & Male & SEM $^{\mathbf{1}}$ & $p$ Value \\
\hline$n$ & 33 & 21 & & \\
Birth weight $(\mathrm{kg})$ & 3.7 & 3.8 & 0.26 & 0.2 \\
Live weight gain $\left(\mathrm{g} \mathrm{day}^{-1}\right)$ & 96 & 130 & 21 & 0.01 \\
Weaning weight $(\mathrm{kg})$ & 9.5 & 11.5 & 1.3 & 0.03 \\
\hline Variable/Birth type & Singleton & Twin & SEM $^{\mathbf{1}}$ & $\boldsymbol{p}$ Value \\
\hline$n$ & 31 & 22 & & \\
Birth weight $(\mathrm{kg})$ & 3.9 & 3.4 & 0.27 & 0.002 \\
Live weight gain $\left(\mathrm{g} \mathrm{day}^{-1}\right)$ & 125 & 98 & 21 & 0.09 \\
Weaning weight $(\mathrm{kg})$ & 11.2 & 9.6 & 1.3 & 0.3 \\
\hline${ }^{1}$ Standard error of the mean from the mixed model output. &
\end{tabular}

\section{Discussion}

Feeding ewes during the last third of pregnancy with Opuntia, with or without protein enrichment, did not improve lamb birth weight or ewe milk yield above the levels seen with alfalfa hay. However, the E-Opuntia treatment accelerated postnatal growth and led to a heavier weight at weaning, compared to feeding either alfalfa or untreated Opuntia. Contrary to expectations, these were the only benefits provided by protein enrichment of Opuntia cladodes, perhaps because the protein content remained relatively low [32]. The impact on birth weight of Opuntia feeding during late gestation has been tested only a few studies, none with protein-enriched cladodes, and the outcomes generally agree with those in the present study. For example, Rekik et al. [15] supplemented Barbarine ewes during late gestation and did not observe any improvement in progeny weight at 10 days postpartum.

It is perhaps important to note that the birth weight reported in the present study was below values previously reported for this breed, at either a similar location [33] or elsewhere [34,35]. This outcome could be attributed to the amount of diet offered which, for all three treatments, did not meet the NRC [28] requirements-the Control diet provided too little energy and both of the Opuntia treatments provided too little protein or energy. This feeding regime was chosen to reflect the real-world situation for reproducing Rambouillet sheep in arid and semiarid regions of northern Mexico. These restrictions can explain the negative live weight gain in the ewes, as well as the lower birth weight of the lambs, in the E-Opuntia and Control treatments [36]. However, in the Opuntia treatment, the ewes did not lose weight, suggesting other factors are involved. A possible hypothesis is that the E-Opuntia intake affected rumen environment [37,38], dry matter intake and digestibility [22,23]. Late gestation is a period of high demand for energy; however, gestational nutritional restriction reduces the concentration of metabolic hormones and induces a catabolic hormonal profile $[18,39,40]$. Nutrient partitioning during gestation generally favors the fetus at the expense of the mother [41,42]. Hence, having in mind the previous literature, it is plausible to assume that the E-Opuntia intake increased the propionate availability in the rumen stimulating glycogenolisis and this would result in weight loss [43]. Nevertheless, fetal growth depends on nutrient availability, which in turn is related to the capacity of the placenta to transport these nutrients. Thus, maternal nutritional restriction in the current experiment may have affected fetal growth and induced a lower birth weight than the average for this breed $[33,44]$. The impact of Opuntia feeding during late gestation has been tested only by one study [15] but maternal body weights were not reported. An Opuntia only diet has been shown to result in weight loss in dry Rumbi ewes, whereas body weight was maintained with a 
combination of Opuntia and straw [45]. Clearly, further research is needed on the nutritional value of Opuntia cladodes and their ability to meet the demands of pregnancy and lactation in sheep that are underfed.

We acknowledge that, in addition to other factors [46-48], heavier females produce heavier offspring at birth $[49,50]$. However, such results were not found in the present study. Despite a lack of differences in birth weight, the lambs in the E-Opuntia group grew faster and were heavier at weaning. Interestingly, Opuntia supplementation has been shown to benefit post-weaning growth and fattening in other studies [14,22]. Barbarine lambs had a greater daily live weight gain when providing barley straw in combination to cactus and soybean meal or atriplex and cactus in comparison to lambs that received atriplex and barley grains [14,22]. Nevertheless, we could only find one comparable study of the impact of Opuntia supplementation on postnatal growth in sheep, and it was done with Barbarine ewes during early lactation. Non-protein-enriched Opuntia was compared to a control diets but, in contrast to the present study, both diets met the nutritional requirements and lamb growth was similar [15]. Among the other major factors affecting lamb growth in the first 8 weeks are genetic background, birth weight, the amount of milk produced by the mother, and solid feed consumption after the fourth week of age [30,51]. Milk composition is an important consideration for explaining differences in postnatal growth. Unfortunately, technical issues prevented us from analyzing milk composition, so this question awaits future studies. Previous studies have demonstrated that the growth performance of lambs is highly related to birth weight, so individuals that are heavier at birth grow faster and are heavier at weaning [30,33,52]. However, in the present study, growth rate was not related to birth weight perhaps because the birth weights were low, as discussed above. In other words, all lambs suffered fetal growth restriction and could therefore have been poorly prepared for post-natal growth to age 8 weeks.

Milk yield influences the growth of the Merino lambs [30] but, in the present study, no such relationship was evident. A similar observation was made in a previous study using only non-enriched Opuntia cladodes [15]. However, we expected milk yield to be improved by feeding protein-enriched Opuntia cladodes. The diet offered during early lactation met the nutritional requirements [28] and the milk output increased as the experiment progressed in all treatments, in a fashion typical of mature ewes [53] but, surprisingly, milk yield was greater in the Control group than in both the Opuntia and E-Opuntia groups. The high demand for energy during gestation and lactation is well known $[18,54]$ suggesting, again, that the present observations can be explained by the effects of the low dietary energy intake on lactogenesis [24]. It seems likely that the protein content in the alfalfa, being greater than that in either of the Opuntia diets, is responsible for the better milk yield in the Control treatment [54]. In goats, milk yields have been found to be similar in control and Opuntia-fed animals, although the diets used in these studies contained many other ingredients that improved nutritive quality $[55,56]$. Nevertheless, our results indicate that, during early lactation in animals that are underfed, feeding Opuntia cladodes can result in moderate milk yield and perhaps reduce production costs. There is some information about how Opuntia feeding affects the yield and composition of colostrum and milk [15,57], but our observations suggest that research is warranted on the use of protein-enriched Opuntia.

The higher weaning weight with E-Opuntia, in the absence of advantages in birth weight or milk yield, might be related to prenatal programming by maternal dietary conditions. As explained above, none of our diets met the NRC requirements for pregnant ewes [28]. Underfeeding can modify fetal programming and lead to changes in metabolic pathways that affect fetal growth and postnatal fat accumulation [58]. The primary muscle fibers are established during embryonic development, with the number of fibers produced being a determinant of potential muscle mass [59,60], although fetal growth during the last third of pregnancy is due to hypertrophy [36]. Concomitantly, fetal adipogenesis begins around mid-gestation [61,62]. It appears that restriction of the maternal diet during gestation would limit the number of muscle fibers but increase the amount of central adipose tissue [63-65], thus compromising fetal growth and postnatal development. Indeed, in sheep, Ford et al. [64] observed 
that progeny from ewes that are underfed during pregnancy are heavier and with more backfat at 140 days of age, leading to the proposition of a positive relationship between intrauterine growth restriction and postnatal catch-up growth.

Finally, lambs born as singletons were heavier at birth than lambs born as twins, after which postnatal growth was similar, indicating catch-up growth by twins [66]. On the other hand, female and male lambs had similar birth weights, despite the widely accepted sexual dimorphism of the fetus [46,47]. In this case, however, postnatal growth was affected and males grew faster and were heavier at weaning than females, perhaps reflecting a more active somatropic axis in males than in females $[67,68]$. Overall, our results are supporting previous data on birth weight, weight gain and weaning weight between singletons and twins and between female and male lambs $[30,33,48,52]$.

\section{Conclusions}

In conclusion, Opuntia ficus cladodes, with or without protein enrichment, can largely match the effects from a supplementation with alfalfa hay during the last third of pregnancy and, showing similar birth weight, milk yield and lamb growth, offer a cost-saving option for industries based in arid and semiarid regions where forage supply is limiting. Protein enrichment of the cladodes seems to have little effect on prenatal growth or milk yield, but appears to improve postnatal growth, thus accelerating weight gain in the lambs. Further research is needed to explore the impact of the supplementation of protein-enriched Opuntia on colostrum and milk composition.

Author Contributions: Conceptualization, V.C.R., M.d.J.F.N., J.U.M. and C.A.R.N.; Data curation, F.S.H. and C.A.R.N.; Formal analysis, V.C.R., M.H.-G., A.C.-C. and C.A.R.N.; Funding acquisition, C.A.R.N.; Investigation, V.C.R., M.d.J.F.N. and C.A.R.N.; Methodology, V.C.R., M.d.J.F.N., C.A.M.-H. and C.A.R.N.; Resources, J.M.V.G., M.H.-G. and A.C.-C.; Supervision, C.A.R.N.; Validation, C.A.M.-H., A.G.-B., G.B.M. and C.A.R.N.; Visualization, C.A.M.-H., A.G.-B., G.B.M. and C.A.R.N.; Writing-original draft, C.A.R.N.; Writing-review \& editing, V.C.R., F.S.H., M.d.J.F.N., J.M.V.G., J.U.M., M.H.-G., A.C.-C., C.A.M.-H., A.G.-B., G.B.M. and C.A.R.N.

Funding: The present study was funded by the National Institute for Research in Forestry, Agriculture and Livestock (INIFAP/project-10561934075).

Acknowledgments: The authors wish to thank Lucino Olvera Sandoval for allowing us to use his animals. In addition, the authors wish to thank all the students from the Facultad de Agronomía y Veterinaria for their assistance in the data collection.

Conflicts of Interest: The authors declare no conflict of interest.

Data Repository Resources: None of the data were deposited in an official repository, yet, information can be available upon request.

\section{References}

1. Tovar-Luna, I. Goat production in Mexico-Overview of the industry and its production practices. In Proceedings of the 24th Annual Goat Field Day, Langston, OK, USA, 25 April 2009.

2. Escareño, L.; Salinas-Gonzalez, H.; Wurzinger, M.; Iñiguez, L.; Sölkner, J.; Meza-Herrera, C.A. Dairy goat production systems. Trop. Anim. Health Prod. 2012, 45, 17-34. [CrossRef]

3. Cuevas-Reyes, V.; Rosales-Nieto, C.A. Characterization of the dual-purpose bovine system in northwest Mexico: Producers, resources and problematic. Rev. MVZ Córdoba 2018, 23, 6448-6460. [CrossRef]

4. Ben Salem, H.; Smith, T. Feeding strategies to increase small ruminant production in dry environments. Small Rum. Res. 2008, 77, 174-194. [CrossRef]

5. Arellano-Rodriguez, G.; Meza-Herrera, C.A.; Rodriguez-Martinez, R.; Dionisio-Tapia, R.; Hallford, D.M.; Mellado, M.; Gonzalez-Bulnes, A. Short-term intake of $\beta$-carotene-supplemented diets enhances ovarian function and progesterone synthesis in goats. J. Anim. Physiol. Anim. Nutr. 2009, 93, 710-715. [CrossRef] [PubMed]

6. Gámez Vázquez, H.G.; Urrutia Morales, J.; Rosales Nieto, C.A.; Meza-Herrera, C.A.; Echavarría Chaires, F.G.; Beltrán López, S. Tillandsia recurvata and its chemical value as an alternative use for feeding ruminants in northern Mexico. J. Appl. Anim. Res. 2018, 46, 295-300. [CrossRef] 
7. Pinos-Rodríguez, J.M.; Duque-Briones, R.; Reyes-Agüero, J.A.; Aguirre-Rivera, J.R.; García-López, J.C.; González-Muñoz, S. Effect of species and age on nutrient content and in vitro digestibility of Opuntia spp. J. Appl. Anim. Res. 2006, 30, 13-17. [CrossRef]

8. El-Mostafa, K.; El Kharrassi, Y.; Badreddine, A.; Andreoletti, P.; Vamecq, J.; El Kebbaj, M.S.; Latruffe, N.; Lizard, G.; Nasser, B.; Cherkaoui-Malki, M. Nopal Cactus (Opuntia ficus-indica) as a source of bioactive compounds for nutrition, health and disease. Molecules 2014, 19, 14879-14901. [CrossRef] [PubMed]

9. Ayadi, M.A.; Abdelmaksoud, W.; Ennouri, M.; Attia, H. Cladodes from Opuntia Ficus Indica as a source of dietary fiber: Effect on dough characteristics and cake making. Ind. Crops Prod. 2009, 30, 40-47. [CrossRef]

10. Rodrigues, A.M.; Pitacas, F.I.; Reis, C.M.G.; Blasco, M. Nutritional value of Opuntia ficus-indica cladodes from Portuguese ecotypes. Bulg. J. Agric. Sci. 2016, 22, 40-45.

11. Russell, C.E.; Felker, P. The prickly-pears (Opuntia spp., Cactaceae): A source of human and animal food in semiarid regions. Econ. Bot. 1987, 41, 433-445. [CrossRef]

12. Torres-Ponce, R.L.; Morales-Corral, D.; Ballinas-Casarrubias, M.L.; Nevárez-Moorillón, G.V. El nopal: Planta del semidesierto con aplicaciones en farmacia, alimentos y nutrición animal. Rev. Mex. Cien. Agríc. 2015, 6, 1129-1142. [CrossRef]

13. Kaur, M.; Kaur, A.; Sharma, R. Pharmacological actions of Opuntia ficus indica: A review. J. Appl. Pharm. Sci. 2012, 2, 15-18. [CrossRef]

14. Ben Salem, H.; Nefzaoui, A.; Ben Salem, L. Spineless cactus (Opuntia ficus indica f. inermis) and oldman saltbush (Atriplex nummularia L.) as alternative supplements for growing Barbarine lambs given straw-based diets. Small Rum. Res. 2004, 51, 65-73. [CrossRef]

15. Rekik, M.; Ben Salem, H.; Lassoued, N.; Chalouati, H.; Ben Salem, I. Supplementation of Barbarine ewes with spineless cactus (Opuntia ficus-indica $\mathrm{f}$. inermis) cladodes during late gestation-early suckling: Effects on mammary secretions, blood metabolites, lamb growth and postpartum ovarian activity. Small Rum. Res. 2010, 90, 53-57. [CrossRef]

16. Rekik, M.; Gonzalez-Bulnes, A.; Lassoued, N.; Ben Salem, H.; Tounsi, A.; Ben Salem, I. The cactus effect: An alternative to the lupin effect for increasing ovulation rate in sheep reared in semi-arid regions? J. Anim. Physiol. Anim. Nutr. 2012, 96, 242-249. [CrossRef] [PubMed]

17. Meza-Herrera, C.A.; Cano-Villegas, O.; Flores-Hernandez, A.; Veliz-Deras, F.G.; Calderon-Leyva, G.; Guillen-Muñoz, J.M.; García de la Peña, C.; Rosales-Nieto, C.A.; Macias-Cruz, U.; Avendaño-Reyes, L. Reproductive outcomes of anestrous goats supplemented with spineless Opuntia megacantha Salm-Dyck protein-enriched cladodes and exposed to the male effect. Trop. Anim. Health Prod. 2017, 49, 1511-1516. [CrossRef]

18. Sadjadian, R.; Seifi, H.A.; Mohri, M.; Naserian, A.A.; Farzaneh, N. Variations of energy biochemical metabolites in periparturient dairy Saanen goats. Comp. Clin. Pathol. 2013, 22, 449-456. [CrossRef]

19. Araújo, L.F.; Medeiros, A.N.; Perazzo Neto, A.; Oliveira, L.S.C.; Silva, F.L.H. Protein enrichment of cactus pear (Opuntia ficus-indica Mill) using Saccharomyces cerevisiae in solid-state fermentation. Braz. Arch. Biol. Technol. 2005, 48, 161-168. [CrossRef]

20. Herrera, E.; Murillo, M.; Berumen, L.; Soto-Cruz, N.O.; Páez-Lerma, J.B. Protein enrichment of Opuntia ficus-indica using Kluyveromyces marxianus in solid-state fermentation. Cienc. Investig. Agrar. 2017, 44, 113-120. [CrossRef]

21. da Conceição, MG.; de Andrade Ferreira, M.; Silva, J.L.; Ferreira Costa, C.T.; Chagas, J.C.C.; Monteiro, C.C.F. Can cactus (Opuntia stricta [Haw.] Haw) cladodes plus urea replace wheat bran in steers' diet? Asian Australas J. Anim. Sci. 2018, 31, 1627-1634. [CrossRef]

22. Ben Salem, H.; Abdouli, H.; Nefzaoui, A.; El-Mastouri, A.; Ben Salem, L. Nutritive value, behaviour, and growth of Barbarine lambs fed on oldman saltbush (Atriplex Nummularia L.) and supplemented or not with barley grains or spineless cactus (Opuntia ficus-indica f. inermis) pads. Small Rum. Res. 2005, 59, $229-237$. [CrossRef]

23. Misra, A.K.; Mishra, A.S.; Tripathi, M.K.; Chaturvedi, O.H.; Vaithiyanathan, S.; Prasad, R.; Jakhmola, R.C. Intake, digestion and microbial protein synthesis in sheep on hay supplemented with prickly pear cactus [Opuntia ficus-indica (L.) Mill.] with or without Groundnut Meal. Small Rum. Res. 2006, 63, 125-134. [CrossRef] 
24. Banchero, G.E.; Clariget, R.P.; Bencini, R.; Lindsay, D.R.; Milton, J.T.B.; Martin, G.B. Endocrine and metabolic factors involved in the effect of nutrition on the production of colostrum in female sheep. Reprod. Nutr. Dev. 2006, 46, 447-460. [CrossRef] [PubMed]

25. Federation Animal Science Society. Guide for the Care and Use of Agricultural Animals in Agricultural Research and Teaching, 3rd ed.; Federation Animal Science Society: Champaing, IL, USA, 2010; p. 177.

26. NAM-National Academy of Medicine. Guide for the Care and Use of Laboratory Animals. Co-Produced by the National Academy of Medicine-Mexico and the Association for Assessment and Accreditation of Laboratory Animal Care International, 1st ed.; Harlan: Mexico City, Mexico, 2010.

27. González de Bulnes, A.; Santiago Moreno, J.; López Sebastián, A. Estimation of fetal development in manchega dairy ewes by transrectal ultrasonographic measurements. Small Rum. Res. 1998, 27, 243-250. [CrossRef]

28. Nuclear Regulatory Commission. Nutrient Requirements of Small Ruminants, Sheep, Goats, Cervids, and New World Camelids, 1st ed.; National Academy Press: Washington, DC, USA, 2007.

29. Rosales Nieto, C.A.; Meza-Herrera, C.A.; Morón Cedillo, F.J.; Flores Najera, M.J.; Gámez Vázquez, H.G.; Cuevas Reyes, V.; Liu, S.M. Effects of vitamin E supply during late gestation and early lactation upon colostrum composition, milk production and quality in nutritional restricted ewes. Small Rum. Res. 2015, 133, 77-81. [CrossRef]

30. Rosales Nieto, C.A.; Ferguson, M.B.; Macleay, C.A.; Briegel, J.R.; Wood, D.A.; Martin, G.B.; Bencini, R.; Thompson, A.N. Milk production and composition, and progeny performance in young ewes with high merit for rapid growth and muscle and fat accumulation. Animal 2018, 12, 2292-2299. [CrossRef]

31. SAS Institute. SAS/Stat User's Guide, Version 9.3; SAS Institute Inc.: Cary, NC, USA, 2010.

32. McNeill, D.M.; Slepetis, R.; Ehrhardt, R.A.; Smith, D.M.; Bell, A.W. Protein requirements of sheep in late pregnancy: Partitioning of nitrogen between gravid uterus and maternal tissues. J. Anim. Sci. 1997, 75, 809-816. [CrossRef]

33. Rosales Nieto, C.A.; Meza-Herrera, C.A.; Moron Cedillo, F.J.; Flores Najera, M.J.; Gámez Vázquez, H.G.; Ventura Pérez, F.J.; Liu, S.M. Vitamin E supplementation of undernourished ewes pre- and post-lambing reduces weight loss of ewes and increases weight of lambs. Trop. Anim. Health Prod. 2016, 48, 613-618. [CrossRef]

34. Bromley, C.M.; Snowder, G.D.; Van Vleck, L.D. Genetic parameters among weight, prolificacy, and wool traits of Columbia, Polypay, Rambouillet, and Targhee sheep. J. Anim. Sci. 2000, 78, 846-858. [CrossRef]

35. Hanford, K.J.; Van Vleck, L.D.; Snowder, G.D. Estimates of genetic parameters and genetic change for reproduction, weight, and wool characteristics of Rambouillet sheep. Small Rumin. Res. 2005, 57, 175-186. [CrossRef]

36. Du, M.; Tong, J.; Zhao, J.; Underwood, K.R.; Zhu, M.; Ford, S.P.; Nathanielsz, P.W. Fetal programming of skeletal muscle development in ruminant animals. J. Anim. Sci. 2010, 88, E51-E60. [CrossRef]

37. Nolan, J.V.; Stachiw, S. Fermentation and nitrogen dynamics in Merino sheep given a low-quality-roughage diet. Br. J. Nutr. 2007, 42, 63-80. [CrossRef] [PubMed]

38. Can, A.; Denek, N.; Yazgan, K. Effect of urea and molasses supplementation on nutrient intake and digestibility of sheep fed with straw. J. Anim. Vet. Adv. 2004, 3, 466-469.

39. Caldeira, R.M.; Belo, A.T.; Santos, C.C.; Vazques, M.I.; Portugal, A.V. The effect of long-term feed restriction and over-nutrition on body condition score, blood metabolites and hormonal profiles in ewes. Small Rumin. Res. 2007, 68, 242-255. [CrossRef]

40. Tygesen, M.P.; Nielsen, M.O.; Nørgaard, P.; Ranvig, H.; Harrison, A.P.; Tauson, A.-H. Late gestational nutrient restriction: Effects on ewes' metabolic and homeorhetic adaptation, consequences for lamb birth weight and lactation performance. Arch. Anim. Nutr. 2008, 62, 44-59. [CrossRef] [PubMed]

41. Parr, R.A.; Williams, A.H.; Campbell, I.P.; Witcombe, G.F.; Roberts, A.M. Low nutrition of ewes in early pregnancy and the residual effect on the offspring. J. Agric. Sci. 1986, 106, 81-87. [CrossRef]

42. Vincent, I.C.; Williams, H.L.; Hill, R. The influence of a low-nutrient intake after mating on gestation and perinatal survival of lambs. Br. J. Nutr. 1985, 141, 611-617. [CrossRef]

43. Tirosh, A.; Calay, E.S.; Tuncman, G.; Claiborn, K.C.; Inouye, K.E.; Eguchi, K.; Alcala, M.; Rathaus, M.; Hollander, K.S.; Ron, I.; et al. The short-chain fatty acid propionate increases glucagon and fabp4 production, impairing insulin action in mice and humans. Sci. Transl. Med. 2019, 11, eaav0120. [CrossRef] 
44. Gaccioli, F.; Lager, S.; Powell, T.L.; Jansson, T. Placental transport in response to altered maternal nutrition. J. Dev. Orig. Health Dis. 2012, 4, 101-115. [CrossRef]

45. Louacini, B.K.; Dellal, A.; Halbouche, M.; Ghazi, K. Effect of incorporation of the spineless Opuntia Ficus Indica in diets on biochemical parameters and its impact on the average weight of ewes during the maintenance. Glob. Vet. 2012, 8, 352-359.

46. Gardner, D.S.; Buttery, P.J.; Daniel, Z.; Symonds, M.E. Factors affecting birth weight in sheep: Maternal environment. Reproduction 2007, 133, 297-307. [CrossRef] [PubMed]

47. Clifton, V.L. Review: Sex and the human placenta: Mediating differential strategies of fetal growth and survival. Placenta 2010, 31, S33-S39. [CrossRef] [PubMed]

48. Rosales Nieto, C.A.; Mantey, A.; Makela, B.; Byrem, T.; Ehrhardt, R.; Veiga-Lopez, A. Shearing during late pregnancy increases size at birth but does not alter placental endocrine responses in sheep. Animal 2020, 14, 799-806. [CrossRef]

49. Oldham, C.M.; Thompson, A.N.; Ferguson, M.B.; Gordon, D.J.; Kearney, G.A.; Paganoni, B.L. The birthweight and survival of merino lambs can be predicted from the profile of liveweight change of their mothers during pregnancy. Anim. Prod. Sci. 2011, 51, 776-783. [CrossRef]

50. Paganoni, B.L.; Ferguson, M.B.; Kearney, G.A.; Thompson, A.N. Increasing weight gain during pregnancy results in similar increases in lamb birthweights and weaning weights in merino and non-merino ewes regardless of sire type. Anim. Prod. Sci. 2014, 54, 727-735. [CrossRef]

51. Lane, M.A.; Baldwin, R.L.; Jesse, B.W. Sheep rumen metabolic development in response to age and dietary treatments. J. Anim. Sci. 2000, 78, 1990-1996. [CrossRef]

52. Ochoa Cordero, M.; Meza Herrera, C.A.; Vázquez García, J.M.; Stewart, C.A.; Rosales Nieto, C.A.; Ochoa Alfaro, A.E.; Purvis, I.A.; Cuevas Reyes, V.; Lee, H.; Martin, G.B. Pregnancy and litter size, but not lamb sex, affect feed intake and wool production by Merino-type ewes. Animals 2019, 9, 214. [CrossRef]

53. Bencini, R.; Pulina, G. The quality of sheep milk: A review. Aust. J. Exp. Agric. 1997, 37, 485-504. [CrossRef]

54. Pulina, G.; Macciotta, N.; Nudda, A. Milk composition and feeding in the Italian dairy sheep. Ital. J. Anim. Sci. 2004, 4, 5-14. [CrossRef]

55. Costa, R.G.; Beltrão Filho, E.M.; Nunes de Medeiros, A.; Naves Givisiez, P.E.; Ramos do Egypto Queiroga, R.C.; Silva Melo, A.A. Effects of increasing levels of cactus pear (Opuntia ficus-indica L. Miller) in the diet of dairy goats and its contribution as a source of water. Small Rumin. Res. 2009, 82, 62-65. [CrossRef]

56. Mahouachi, M.; Atti, N.; Hajji, H. Use of Spineless Cactus (Opuntia ficus indica F. Inermis) for dairy goats and growing kids: Impacts on milk production, kid's growth, and meat quality. Sci. World J. 2012, 2012. [CrossRef] [PubMed]

57. Costa, R.G.; Beltrão Filho, E.M.; Ramos do Egypto Queiroga, R.C.; Suely Madruga, M.; Nunes de Medeiros, A.; Bruno de Oliveira, C.J. Chemical composition of milk from goats fed with cactus pear (Opuntia ficus-indica L. Miller) in substitution to corn meal. Small Rumin. Res. 2010, 94, 214-217. [CrossRef]

58. Fleming, T.P.; Lucasm, E.S.; Watkins, A.J.; Eckert, J.J. Adaptive responses of the embryo to maternal diet and consequences for post-implantation development. Reprod. Fertil. Dev. 2011, 24, 35-44. [CrossRef] [PubMed]

59. Dwyer, C.M.; Fletcher, J.M.; Stickland, N.C. Muscle cellularity and postnatal growth in the pig. J. Anim. Sci. 1993, 71, 3339-3343. [CrossRef]

60. Rehfeldt, C.; Fiedler, I.; Dietl, G.; Ender, K. Myogenesis and postnatal skeletal muscle cell growth as influenced by selection. Livest. Prod. Sci. 2000, 66, 177-188. [CrossRef]

61. Gnanalingham, M.G.; Mostyn, A.; Symonds, M.E.; Stephenson, T. Ontogeny and nutritional programming of adiposity in sheep: Potential role of glucocorticoid action and uncoupling protein-2. Am. J. Physiol. Regul. Integr. Comp. Physiol. 2005, 289, R1407-R1415. [CrossRef]

62. Muhlhausler, B.S.; Duffield, J.A.; McMillen, I.C. Increased maternal nutrition stimulates peroxisome proliferator activated receptor- $\gamma$, adiponectin, and leptin messenger ribonucleic acid expression in adipose tissue before birth. Endocrinology. 2007, 148, 878-885. [CrossRef]

63. Greenwood, P.L.; Hunt, A.S.; Hermanson, J.W.; Bell, A.W. Effects of birth weight and postnatal nutrition on neonatal sheep: II. Skeletal muscle growth and development. J. Anim. Sci. 2000, 78, 50-61. [CrossRef]

64. Ford, S.P.; Hess, B.W.; Schwope, M.M.; Nijland, M.J.; Gilbert, J.S.; Vonnahme, K.A.; Means, W.J.; Han, H.; Nathanielsz, P.W. Maternal undernutrition during early to mid-gestation in the ewe results in altered growth, adiposity, and glucose tolerance in male offspring. J. Anim. Sci. 2007, 85, 1285-1294. [CrossRef] 
65. Taylor, P.D.; Poston, L. Developmental programming of obesity in mammals. Exp. Physiol. 2007, 92, $287-298$. [CrossRef]

66. Thompson, A.N.; Ferguson, M.B.; Campbell, A.J.D.; Gordon, D.J.; Kearney, G.A.; Oldham, C.M.; Paganoni, B.L. Improving the nutrition of Merino ewes during pregnancy and lactation increases weaning weight and survival of progeny but does not affect their mature size. Anim. Prod. Sci. 2011, 51, 784-793. [CrossRef]

67. Gatford, K.L.; Fletcher, T.P.; Clarke, I.J.; Owens, P.C.; Quinn, K.J.; Walton, P.E.; Grant, P.A.; Hosking, B.J.; Egan, A.R.; Ponnampalam, E.N. Sexual dimorphism of circulating somatotropin, insulin-like growth factor I and II, insulin-like growth factor binding proteins, and insulin: Relationships to growth rate and carcass characteristics in growing lambs. J. Anim. Sci. 1996, 74, 1314-1325. [CrossRef] [PubMed]

68. Gatford, K.L.; Quinn, K.J.; Walton, P.E.; Grant, P.A.; Hosking, B.J.; Egan, A.R.; Owens, P.C. Ontogenic and nutritional changes in circulating insulin-like growth factor (IGF)-I, IGF-II and IGF-binding proteins in growing ewe and ram lambs. J. Endocrinol. 1997, 155, 47-54. [CrossRef] [PubMed]

(C) 2020 by the authors. Licensee MDPI, Basel, Switzerland. This article is an open access article distributed under the terms and conditions of the Creative Commons Attribution (CC BY) license (http://creativecommons.org/licenses/by/4.0/). 